\title{
The analysis of international experience in the energy market formation and economic mechanisms for management of the gas supply systems
}

\author{
N. V. Varlamov ${ }^{1, *}$ \\ ${ }^{1}$ Gazprom Promgaz JSC, Vidnoe, Russia
}

\begin{abstract}
The article assesses the foreign countries experience in formation of the energy market and the basics of managing the development of gas supply systems. The creation of a system in order to provide access to gas transport services for gas consumers, gas producers and its suppliers, as well as the creation of favorable conditions for investment is a significant stage in the implementation of effective market transformations. One of the fundamental points for carrying out the reforms in gas industry in the market conditions should be the arrangement of trade system for reserved capacities. The positive results of the reform include: reduction or stabilization of prices for end-users, diversification of gas supply sources, improvement of the gas supply reliability.
\end{abstract}

\section{Introduction}

Currently, the instability of world oil prices, the drop of investments in energy market, the backlog of gas reserves growth from production volumes, the degradation of key assets, have a negative impact on the energy market and on the development of gas supply systems in Russia [1-5]. In this regard, it seems relevant to conduct an analysis of foreign experience in energy market formation and mechanisms for managing the development of gas supply systems. The main objective of the study is to form the understanding of the particularities of the energy markets functioning in various countries and to identify key areas for improvements in Russia.

\section{Key trends in the formation of energy markets}

Today, the following trends are characteristic for global energy markets [6-9]:

- change in the direction of commodity flows from countries with developed market to countries with developed market;

- impact of technological disasters on the consumption of various energy products;

- changes in tax, customs and environmental laws of many countries;

- change of energy resources consumption, sources to satisfy the demand under influence of the development of scientific and technological progress;

- increasing of dependence on the results of scientific and technological progress;
- globalization of world energy markets and integration processes;

- liberalization of energy markets of individual countries.

The limitation factors in the development of the energy market are:

- high degree of deterioration of fixed assets;

- cross-subsidization;

- excess of heat power;

- Non-payments and low investment opportunities.

Since traditionally national governments are responsible for the reliability of energy supply, it is the State that has a significant influence on creating conditions for the formation of an energy market and for the formation of an economic mechanism for managing the elaboration of gas supply systems in most developed countries [10], [11].

For example, many countries have adopted legislative decisions in order to divide the monopoly types of business activities in the gas sector (transport and storage of gas) from the gas production and sales, where the development of competition can be more easily achieved.

\section{Analysis of the key directions to develop the competitive gas market}

Deep market changes in the gas industry abroad were initiated due to the need to increase the efficiency of gas markets, also in order to reduce consumer costs.

Reforms were initiated in the 1980s by the most developed countries - Canada, the USA and Great Britain [7-9]. European Union countries joined the gas market transformation in the late 1990s. Currently, the

\footnotetext{
*Corresponding author: twelve12chairs@gmail.com
} 
countries with rich gas resources, such as Argentina, Australia, and New Zealand, have also introduced market principles into their energy sector. In the most developed countries, the transition can be stated in the gas industry from the "seller's market" to the "consumer market". These countries have gone through a period of active gasification, the number of new consumers is no longer growing at the same pace, and gas producers and sellers are forced to compete for existing consumers, creating more attractive offers for consumers.

Competition in the gas sector can have a negative impact on its efficiency, if the prerequisites for a competitive market did not previously exist, and their creation requires excessively high investments. For example, in France there is still significant state participation in gas distribution and transportation. $[12,13]$.

The objectives of any State in the development of energy markets, in addition to reliable supply for gas consumers and developing of "inter-fuel" competition, should also be the creation of favorable conditions for investment in the effective development of new deposits and the construction of gas transportation systems.

The principles of the state policy for the gas industry reformation include a balance of state regulation and price liberalization in order to establish an attractive investment regime in the energy sector. [14-17].

When carrying out the structural changes to improve the efficiency of the existing mechanism for the gas industry management as a whole, it is necessary to pay attention to the following main "transformations".

To improve the efficiency of existing, as well as the introduction of new gas transportation and storage facilities, it is necessary to consider various options for attracting and further assuring of the investments by state legislative and regulatory bodies.

The organization of a trade system for the reserved capacities as the formation of a "secondary market" for gas transportation and gas storage capacities should become an extremely important stage for carrying out reforms in the gas industry under market conditions.

The analysis of world experience in gas supply systems shows the necessity to maintain export gas supplies under long-term contracts in order to obtain guarantees for gas consumers. For manufacturers, these contracts provide confidence in providing the investments that are so necessary to increase the growth rate of the gas sector. At the same time, it is necessary to expand opportunities for small foreign gas consumers to acquire gas under short-term flexible contracts, taking into account spot prices in gas hubs for European consumers, in order to expand the share of the European market and to provide more flexible supply schedule in the context of fluctuating energy prices and existing dependence of gas prices from oil with a certain time lag.

At the level of international gas trade, access to the energy markets of the counterparty countries should be consistent with the terms of the already concluded longterm gas supply contracts, taking into account the specifics of gas trade between different countries.
The functioning of the gas market should take place with a very high degree of transparency. The development of mandatory standards for information disclose related to use of the gas transportation infrastructure is carried out in order to enable counterparties to analyze prices and tariffs for gas on the energy market, availability of free capacities, and basic open conditions of concluded contracts.

Considering the countries in which the reformation of gas markets was carried out successfully, it can be noted that:

- In general, as a result of the reform, there was a decrease or stabilization of prices for final consumers, with stabilization or increase in gas production.

- Further diversification of gas supply sources did not lead to a decrease in the reliability of gas supply; on the contrary, the system of balancing supplies to consumers had increased its efficiency.

- The creation of non-discriminatory conditions in order to access the gas transportation infrastructure led to a redistribution in the benefit of consumers of "monopoly rent", which was previously distributed between the main participants in the production, transportation and sale of gas [17], [18] .

Despite the fact that the gas markets of different countries have their own unique features and this fact is associated with the choice of a mechanism for regulating the gas supply system, the gas market should not be considered outside its relationship with other energy markets.

For example, about $50 \%$ of industrial consumers in the United States use power plants suitable for both natural gas and liquid fuels. Therefore, US energy security is assessed not in terms of competition between gas supply options, but in terms of the efficiency of inter-fuel competition.

At the same time, prices for energy carriers, including natural gas, are not regulated in the USA, in contrast to tariffs and prices for gas transportation services through trunk and distribution networks (as a naturally monopolistic type of activity). At the same time, the tariff level for main gas pipeline systems differs: higher tariffs are set for new pipelines for the period of their payback, lower - for existing facilities.

\section{Results}

Fluctuations in energy prices in the world, the decrease of profitability of oil and gas fields and increasing investment risks create the need for a more careful study of long-term energy market performance indicators and the search for alternatives, the complexity of inter-fuel competition, and the integrated development of the region.

Summarizing the experience of transformations in the gas industry of developed countries, taking into account all their specific differences, requires consideration of two main groups of countries that have completed quite successfully the reforms in energy sector: North American and European groups. 
The North American model for regulating the gas industry (USA and Canada) stands out due to the isolation of American energy markets from the rest of the world for a sufficient time and the fact that closely interconnected private companies dominate in the region. Regulation went in parallel at several levels: at the federal government level and at the state level.

In the European model at the same time period, the main factor in the development of gas markets was policy at the national level.

The experience of foreign countries in the development of a competitive gas market shows that the main stage of effective market transformation is the creation of a "third party" access system (gas consumers, gas producers and its suppliers, transportation companies) to gas transportation services in the form of non-discriminatory rights to use gas pipeline transportation systems and gas storage facilities [11]. In order to respect such rights, it is required to have the existing balanced mechanism for regulating the industry, which includes various elements. It can be both the regulation of tariffs for gas transportation and its storage as a natural monopoly type of activity by some independent regulator and legislative regulation of the rules and conditions for providing access to the gas transmission network, and open mechanisms for balancing gas supplies to ensure continuity and security of gas supply in the form of new regulatory mechanisms such as the gas spot market and gas futures.

Based on the comparative analysis of world experience in organizing, conducting and regulating the gas industry, it is advisable to draw the following main conclusions:

1) The use of foreign experience for Russia seems appropriate in matters of interaction between government agencies and gas companies with end consumers of gas in order to simultaneously expand consumption and increase the level of social-economic development of the regions.

2) The gas industry in most countries, except the US, was a vertically integrated monopoly structure with gas production, transportation and marketing. But in order to improve efficiency, as well as in the interests of consumers, the question arises of demonopolizing the gas industry.

3) The North American experience of interaction between state social and financial bodies, gas supply organizations and the citizens in the conditions of nonpayment for gas supplied by co-financing gas equipment installations, developing gas payment plans and providing targeted financial assistance may become relevant for the Russian gas industry.

4) The recent trend towards liberalization of the gas markets, and the gradual replacement of long-term contracts with spot gas market has significant importance among foreign countries, including the European gas markets [19-21]. To reduce the costs of gas supply in Russia, it is necessary to ensure the development of perfect competition.

\section{References}

[1]. A.A. Kalyutik, D.V. Grigorieva, A.V Fedyukhin, O.V. Derevianko, I.G. Akhmetova, Reduction of the technological minimum by bypass method with environmental impact estimation on the example of energy blocks with T-100 and T-250/300240 turbines, IOP Conference Series: Earth and Environmental Science, 288(1),012094 (2019)

[2]. E. Sukhareva, A. Fedyukhin, O. Derevianko, M. Egorov, L. Mukhametova, I. Akhmetova, Optimization of combined heat and power plant operating mode by means of underutilized equipment mothball, IOP Conference Series: Earth and Environmental Science, 288(1),012122 (2019)

[3]. Y. Matveev, M. Cherkasova, V. Rassokhin, K. Lapshin, N. Kortikov, R. Ivanovski, E. Yurevich, S. Vokhmyanin, V. Popov, I. Akhmetova, Determination of the optimal working fluid for the turbine recovering combustion engine exhaust gases heat, E3S Web of Conferences, 91,01001 (2019)

[4]. O.A. Stepanov, N.V. Rydalina, E.O. Antonova, B.G. Aksenov, O.V. Derevianko, I.G. Akhmetova, P. Zunino, The possibility of increasing the operating efficiency of gas turbines at compressor stations of main gas pipelines, International Journal of Civil Engineering and Technology, 10(2), 2130-2137 (2019)

[5]. V.I. Sitas, A.V. Fedyukhin, I.G. Akhmetova, A. Mitrofanov, S.O. Makoev, A. Asadpoori, A.A. Sinitsyn, E.A. Kikot, Assessment of technical and economic efficiency indicators of cogeneration in modern market conditions, International Journal of Civil Engineering and Technology, 10(2), 2106-2117 (2019)

[6]. N.G. Ostroukhova, Current Status and Key Trends in the Development of World Energy Markets: Implications for Russia, Vestnik NSU, Series: Socioeconomic sciences. 12(2), 23-35 (2015)

[7]. Natural gas in the United States https://en.wikipedia.org/wiki/Natural_gas_in_the_United States

[8]. Natural Resources Canada https://www.nrcan.gc.ca/energy-facts/natural-gasfacts $/ 20067$

[9]. British Gas https://www.britishgas.co.uk/

[10]. Federal Energy Regulatory Commission https://en.wikipedia.org/wiki/Federal_Energy_Regulator y Commission

[11]. Ofgas

https://en.wikipedia.org/wiki/Office_of_Gas_and_Electri city Markets

[12]. K.V. Gugkaev, Foreign experience and the Russian practice of the gas industry development, the abstracts for PhD, Moscow 2009 https://www.econ.msu.ru/cmt2/lib/a/1483/file/Gugkaev.p df

[13]. Y.M.S. Ovakim Fuel and energy industry of France. France is on the verge of change: economics and politics at the beginning of the XXI century. Collection of articles on the results of the All-Russian Scientific Conference ( IMEMO RAS) 2015 https://mgimo.ru/upload/iblock/e3f/\%D0\%A4\%D1\%80 $\% \mathrm{D} 0 \% \mathrm{~B} 0 \% \mathrm{D} 0 \% \mathrm{BD} \% \mathrm{D} 1 \% 86 \% \mathrm{D} 0 \% \mathrm{~B} 8 \% \mathrm{D} 1 \% 8 \mathrm{~F} \% 20 \%$ 
D0\%A2\%D0\%AD\%D0\%9A\%20(\%D0\%BA\%D0\%BE

$\%$ D0\%BD $\%$ D1\%84\%D0\%B5\%D1\%80\%D0\%B5\%D0

$\%$ BD $\%$ D1\%86\%D0\%B8\%D1\%8F).pdf

[14]. Russia's energy strategy for the period up to $2030 \mathrm{https} / / /$ minenergo.gov.ru/node/1026

[15]. V.Yu. Golubchikova International practice in the field of state regulation of the fuel and energy complex https://researchjournal.org/economical/mezhdunarodnaya-praktika-voblasti-gosudarstvennogo-regulirovaniya-toplivnoenergeticheskogo-kompleksa/

[16] I.Yu. Mironova, Gas pricing mechanisms in the world: a review by region, globalization issues and conclusions for Russia, St. Petersburg, 2015 https://eu.spb.ru/images/centres/ENERPO_RC/Reports/2 015_Mironova.pdf

[17]. V.I. Feigin, The experience of transformations in the gas industry in foreign countries http://gasforum.ru/zarubezhnyj-opyt/202/

[18]. World experience in the implementation of market transformations in the gas sector and the reorganization of the system for providing third party access to gas transmission networks, ERTA Group http:/gasforum.ru/obzory-i-issledovaniya/498/

[19]. World experience in regulating and reforming the gas industry Group, http://gasforum.ru/zarubezhnyj-opyt/216/ (2007)

[20]. E. Orlova, New EU Gas Market Architecture. Long-term contracts vs spot // " Oil \& Gas Journal Russia

https://fief.ru/img/files/112015 stat Oil\&GasJournal EOrlova.pdf (2015)

[21]. The analysis of foreign natural gas markets liberalization http://gasforum.ru/ 